\title{
Employment outcomes and patterns of real estate graduates: Is gender a matter?
}

\section{Structured Abstract:}

\section{Purpose}

The aim of this paper is to investigate whether gender has an impact on real estate and built environment graduates' employment outcomes, employment patterns and other important employment related issues, such as pay, role, contract type and employment opportunity in different States of a country.

\section{Design/methodology/approach}

The data used in this paper has been collected from the Australian Graduate Survey (AGS). Data from the years 2010-2012 was combined into a single dataset. Dimensionality reduction was used to prepare the dataset for the courses listed in AGS data, in order to develop the simplified classifications for real estate and built environment courses which are used to conduct further analysis in this paper. Dimensionality reduction was also used to prepare dataset for the further analysis of the employment outcomes and patterns for real estate graduates. Descriptive and statistical analysis methods were used to identify the impact of gender on the employment outcomes, employment patterns and other important employment related issues, such as pay, role, contract type and location of job, for real estate graduates in Australia. This paper also benchmarks the employment result of real estate graduates to built environment graduates.

\section{Findings}

Recent male built environment graduates in Australia are more likely to gain full-time employment than females. The dominant role for recent female built environment graduates in Australia is a secretarial or administrative role while for the male it is a professional or technical role. Male real estate and built environment graduates are more likely to have a higher level of salary. Gender also has an impact on the contract type. Male built environment graduates are more likely to be employed on a permanent contract. On the other hand, gender has no impact on gaining employment in different States, such as New South Wales and Queensland, in Australia.

The finding of this paper reinforces the view of previous literature, which is that male graduates have a more favourable employment outcomes and on better employment terms. The finding also shows that graduate employment outcomes for real estate and built environment graduates in Australia are similar to that in other countries, such as the UK, where equivalent studies have been published.

\section{Originality/value}

This is pioneering research that investigates the impact of gender on employment outcomes, employment patterns and other employment related issues for real estate graduates and built environment graduates in Australia.

\section{Keywords:}

Australian Graduate Survey (AGS), Built Environment, Employment outcomes and patterns, Graduates, Real Estate

\section{Article Classification:}

Research Paper 


\section{Introduction}

There were extensive discussions on the inequality between males and females and its effect graduate employment outcomes, employment patterns, salary scale and nature of role in general and for the construction sector (Artess et al., 2008; Bilbo et al., 2014; Connor et al., 1997; Dainty et al., 2000; Elias et al., 1999; Fielden et al., 2000; McKnight, 1999; Smith et al., 2000; Staffansson Pauli, 2013). The findings of these previous studies concluded that females usually had less careers prospects and were employed on less favourable terms, such as temporary and part-time contracts and at a lower salary level. However, there is a lack of research focusing on a comparison between employment outcomes and patterns for real estate graduates and built environment graduates.

The aim of this paper is to investigate whether gender has an impact on real estate graduates' employment outcomes, employment patterns and other important employment related issues, such as salary, role, contract type and employment opportunity in different States in Australia. This paper will also benchmark findings of the employment outcomes, patterns and employment related issues through a comparison between real estate graduates and the built environment graduates. This paper is divided into four sections. The first section is a literature review on gender and employment. The second section describes the research method of the paper. It also discusses the process of producing the dataset from the raw data of the Australian Graduate Survey (AGS) for the further analysis in this paper. The third section is a discussion of the research findings. The fourth section is the conclusion.

\section{Literature Review}

\subsection{Gender and employment}

There is a high level of gender imbalance in the construction sector and this situation has not changed significantly in the past several decades. Court and Moralee (1995) reported that the construction industry employed around 1.77 million people, of which, under $10 \%$ are women. Another study conducted by Fielden et al. (2000) reported that there were over 11 million women employed in the UK, accounting for $49.5 \%$ of the workforce. However, at that time it was the case that only $13 \%$ of the industry workforce was female. Despite an increase from the mid 1990s females are still seriously under-represented in the construction sector. Gender imbalance also existed in the construction sector in the USA. In 2003 the percentage of females working in the construction industry in USA was 9.6\% (Avera, 2007) and in 2008 was 10.6\% (Cartwright et al., 2011). This gender imbalance in the construction industry also occurs in Australia. Despite federal and state specific legislative developments in the 1980s, such as the Sex Discrimination Act of 1984, the Affirmative Action Act of 1986 and the Victorian Building Industry Agreement of 1989, which aimed to improve the gender balance in the construction industry in Australia, the women's participation rates in the construction industry have not altered in the long run (Francis and Prosser, 2014). Women represented about $14 \%$ of the workforce in the Australian construction industry in 1995 (Lingard and Lin, 2004), indicating a higher percentage than both the USA and the UK, but the percentage in 2006 had reduced to 13.3\% (Francis, 2010). Pyke (1993) commented the construction industry to be 'a traditional, blue collar, male dominated, craft based industry, resistant to women's participation' (cited in Gilbert and Walker, 2001: p.59).

McKnight (1999) reported on the result of a survey of approximately 11,000 graduates in 1995 from 33 higher education institutions in the UK, tracking their early career paths over the first three and a half years. The results suggested that gender is one of the factors affecting graduates' early career trajectories. The findings of Smith et al.'s (2000) analysis of official data for First Destination Survey (FDS), conducted by Careers Offices of each university and deposited with the Higher 
Education Statistics Agency (HESA) in the UK also shared the same finding. Elias et al. (1999) and Smith et al. (2000) studied the difference on employment outcome for undergraduate leavers in the UK. Their findings indicated that more male undergraduate leavers were unemployed but at the same time a higher proportion of them worked in graduate level occupations. Similar patterns were also reported for postgraduate leavers by Artess et al. (2008). The employment patterns of male and female also differ, with $92 \%$ of men being employed in full-time positions compared with only $55 \%$ of women (Fielden et al., 2000). This situation is even more apparent in the construction industry, where in $199643 \%$ of women were employed in part-time positions compared with only $2 \%$ of men (EOC, 1997).

Gender also has an influence on career path and career progression. Dainty et al. (2000), Gale (1994), Fielden et al. (2000), Greed (2006) and Gurjao (2007) stated that females are more likely to be employed in supporting, secretarial and administrative roles. Fielden et al. (2000) clarified that, despite almost two thirds of women working in secretarial or clerical roles, this statistic is misleading on some levels. After more detailed analysis of the data and the different categories, which are managers, administrators, professional and technical staff, it was revealed that women are concentrated in specialist positions, including personnel and public relations, rather than mainstream managerial positions. The detailed analysis also showed that women are significantly under-represented in the engineering and technical occupations, as compared to their male counterparts, within the technical and professional categories (Clarke and Wall, 1998; Dainty and Lingard, 2006; Greed, 2000; Staffansson Pauli, 2013; Watts, 2009). Greed (2000) stated that females comprised less than $6 \%$ of the $15 \%$ of construction professionals who are in managerial positions. Dainty and Lingard (2006) also stated women represented just $1 \%$ of total employment in site-based technical roles in the U.K. It is the same case for the USA, according to the National Association of Women in Construction (2010), were only $9 \%$ of the total construction workforce is female, and only about $13 \%$ work in management roles. Dainty et al. (2000) investigated women's employment opportunities and career progression patterns in large construction companies. They identified that females have a higher frequency of changing employment, and are less likely to work on large and prestigious projects. They concluded that due to these disadvantages, female construction graduates are likely to be adversely affected in their promotion opportunities and career development. Dainty et al. (2000), Fielden et al. (2000), Devaney and Roberts (2012) and Kaewsri and Tongthong (2014) studied the causes of gender imbalance in the construction sector. These studies indicated the barriers for females entering the construction industry and having successful careers arise from a number of sources including: the construction industry's image; career knowledge amongst children and adults; selection criteria and male dominated courses; recruitment practices and procedures; sexist attitudes; male dominated culture; and the work environment (Dainty et al,. 2000; Fielden et al., 2000 and Devaney and Roberts, 2012).

Artess et al. (2008) and Elias et al. (1999) found that male graduates usually have favourable salary differences compared to female graduates in the UK. Employment Service (1997) reported the same findings. This stated that the earnings of women employed in full-time positions are on average only $78 \%$ of the hourly rate attained by men. This is even worse in the construction industry, where full-time non-manual women workers earn less than $60 \%$ of that paid to their male counterparts. However, it is a more equivalent situation in the USA, where females have similar salaries to their male counterparts and this situation has been consistent for more than two decades (Bilbo and White, 1999 and Bilbo et al., 2014). Bilbo and White (1999) reported that female graduates of established construction education programmes earn equivalent jobs and competitive entry-level salaries. The U.S. Department of Labor (2010) also reported that women in construction made $92.2 \%$ of men's weekly salaries in the USA.

Gender has an impact on the employment pattern in Australia. Based on the statistics from the Australian Bureau of Statistics (ABS), males have a consistently higher employment to population ratio than females during the period from 2004-2005 to 2013-2014, but the difference in the ratio is 
getting smaller. The male and female employment to population ratios in 2004 was $74.9 \%$ and $59.1 \%$ respectively, while in $2013-2014$ were $74.4 \%$ and $61.7 \%$ (ABS, 2015a). There are also a higher proportion of females employed on a part-time basis. In $2004-2005,11.7 \%$ and $42.4 \%$ of part-time workers were males and females respectively, while in 2013-2014, the proportion has changed to $14.4 \%$ and $43.4 \%$ (ABS, 2015a). The unemployment rates for females are slightly higher than males until 2012-2013 and their unemployment rates were $4.7 \%$ and $4.6 \%$, but the unemployment rate has become the same in 2013-2014, which is 5.1\% (ABS, 2015a). Females in Australia earn $18.2 \%$ less than men and the ABS statistics showed that the gender gap between male and female pay was at a 20-year high in 2014 (Evershed, 2014).

\subsection{Research gap and development of research hypotheses}

Research on gender and employment has been a popular topic in several built environment subdisciplines, such as construction (Bilbo, and White, 1999; Bilbo et al., 2014; Dainty et al., 2000; Dainty and Lingard, 2006; Francis, 2010; Francis and Prosser, 2014; Gale, 1994; Gilbert and Walker, 2001; Greed, 2000 and 2006; Gurjao, 2007; Lingard and Lin, 2004), engineering (Kaewsri and Tongthong. 2014; Watts, 2009) and building (Court and Moralee, 1995; Pyke, 1993), There is only one study which considered gender and employment for real estate graduates (Davaney and Roberts, 2014), but gender was examined as one of the eight demographic factors which influences graduate employment in the UK. The paper considered real estate graduates as one of the four built environment subject groups, such as quantity surveying, building surveying, construction and land and property management. Staffansson Pauli's (2013) research had a single focus on gender in real estate, but the purpose of the paper was to create an understanding of the gender structure in the real estate industry of Sweden, but not of gender and real estate graduate employment. There were several gender and employment research which had an Australian focus, such as Francis (2010), Francis and Prosser (2014), Lingard and Lin (2004) and Gilbert and Walker (2001) but these studies have focus in the construction sector. There is yet to have research focusing on gender and real estate graduate employment in Australia,

The previous literature concluded that women are under-represented and have a lack of career prospects in the construction industry. Women are also more likely to be working in a secretarial or administrative role and there is a salary difference between male and female. However, there is a lack of study focused on gender issues in the real estate sector. Staffansson Pauli (2013) has shared the same view and she stated that 'having conducted a literature review of the real-estate industry, the conclusion is that the gender issue so far has been more or less overlooked' (p.424).

There has been no previous literature investigating the type of contract which male and female built environment graduates have. There are a lot of previous literature discussing females are likely to be employed on less favourable terms than males (Artess et al., 2008; Bilbo and White, 1999; Bilbo et al., 2014; Elias et al.,1999 and Fielden et al., 2000). Type of contract, i.e. permanent or temporary contract, is a useful indicator for graduate employment status. This is further reinforced by Scurry and Blenkinsopp's (2011) comment. They stated that graduates involuntarily employed at temporary, fixed term or casual contract can be classified as underemployed. Previous literature also did not consider if there is a difference between male and female employment outcomes in different States of a country. Based on the Australian Bureau Statistics (ABS, 2015b), there were 3,005,100 and 3,109,400 male and female civilian population living in New South Wales respectively in November 2014. Out of them 1,971,700 and 1,654,200 males and females were employed, which gives the employment to population ratio for male and female as $65.61 \%$ and $53.20 \%$. There were 1,873,400 and 1,926,000 male and female civilian population living in Queensland. The number of males and females employed was 1,251,100 and $1,105,900$ respectively. The employment to population ratios for males and females in Queensland was $66.78 \%$ and $57.42 \%$. In other words, males are more likely to secure employment in both states. 
This paper aims to fill this research gap. The following research hypotheses are derived from the review of existing literature and Australian Bureau Statistics (ABS):

1. Male graduates are more likely to gain employment

2. Male graduates are more likely to secure full-time employment

3. Male graduates are more likely to work in professional or technical roles

4. Male graduates are more likely to earn a higher salary

5. Male graduates are more likely to gain permanent employment

6. Male graduates are more likely to gain employment in the states of New South Wales and Queensland

\section{Research method}

\subsection{Data source}

The data used in this paper has been collated from the Australian Graduate Survey (AGS) (AGS, 2015). AGS is a national census of newly-qualified higher education graduates that has been in operation since 1972. The survey is conducted approximately four months after the students have completed the requirements for their awards. The AGS sends its surveys to new graduates from all Australian universities, as well as a number of higher education institutes and colleges.

The data used in this paper is longitudinal and dates from 2010 to 2012 . Surveys conducted by the AGS prior to this were substantially different and therefore pre-2010 data is not compatible with this study and has not been used.

Other similar studies conducted in the UK, such as Smith et al. (2000) and Devaney and Roberts (2012) also used the government statistics on graduate destination. Smith et al. (2000) used First Destination Survey (FDS), conducted by Careers Offices of each university and deposited with the Higher Education Statistics Agency (HESA) and Devaney and Roberts (2012) used HESA Destination of Leavers from Higher Education (DLHE) dataset. Davaney and Roberts (2012) used a four year longitudinal data (2005/06 to 2008/9) while Smith et al. (2000) has only used one year (1983) data. The current study used a similar type of government employment statistics for a three-year period.

\subsection{Validity of Data}

Despite the Australian Graduate Survey (AGS) being statistics produced by the Australian government, the use of AGS data is not without problems. This is the same situation faced by Smith et al. (2000) for using FDS dataset and Davaney and Roberts (2012) using DLHE dataset in the UK. The first problem for this research is the incomplete response rate. The survey response rate for domestic graduates, which is the primary focus of the AGS, typically ranges from 60 to 65 per cent. There is no information on the response rate recorded for the overseas students. The second problem is the time when the survey is conducted. The graduates are invited to complete the survey only four months after the completion of their courses, and this may be too early to conclude their employment situation.

Despite a less than complete response rate for the Australian Graduate Survey, AGS is the most comprehensive graduate survey in Australia and provides detailed information on a large enough sample of university graduates to produce a statistically sound data analysis. McKnight (1999) stated that gaining employment within six months is a good indicator for measuring graduate labour market difficulties. McKnight's (1999) study of the 1995 UK graduates' employment 
destination indicated that graduates who remain unemployed after six months are typically unemployed for more than one year during the first three and a half years after finishing their degree. This compares with an average duration of unemployment of one month for graduates who were employed within six months of graduation. Unemployment at six months after graduation is also associated with a higher probability of being employed in a non-graduate occupation in the future (McKnight, 1999). Although the AGS survey is completed four months after the graduates finish their degree, it can still provide some level of indication of their employment prospects.

\subsection{Dimensionality reduction}

Dimensionality reduction was used to prepare the dataset required for conducting further analysis in this paper, from the raw data of AGS. The R programming language was used to combine the three years of of AGS data (2010-2012) into one dataset and perform the dimensionality reduction. Dimensionality reduction is the process of reducing the number of random variables under consideration. The reason for dimensionality reduction in this paper was feature extraction. Feature extraction aims to transform data in the high-dimensional space to a space of fewer dimensions. The data transformation within this project is linear, as in principal component analysis (PCA). In other words, the dimensionality reduction process of the AGS data within this paper reduces the number of columns in the dataset and replaces all of the columns in the data with a smaller number of columns that have a unique value for every row. In addition to dimensionality reduction, summary statistics were also used to produce a simpler classification of rows of data (Conway and White, 2012).

Dimensionality reduction was used to produce categories for built environment courses. After reviewing the course titles provided under AGS classification and the written information about the Course Majors which graduates studied, the classification for built environment courses was produced including Architecture, Construction, Real Estate and Urban Design and Regional Planning. Please see Table 1 for further information on the types of courses included under each category. In addition, the authors also reviewed information contained in the columns, which states the graduates' Course Majors (up to four majors can be identified) and identifies the graduates who study built environment related courses and included them into the respective groups together. If the graduates indicated that they were studying more than one course major, the authors have grouped them according to information based on their Course Major One.

\section{INSERT TABLE 1 HERE}

In total, there are 9206 built environment graduates in 2010-2012. Out of them, 4156 studied Architecture, 2011 studied Construction, 1258 studied Real Estate and 2117 studied Urban Design and Regional Planning. A number of built environment graduates studied double or triple majors with more than one built environment disciplines, therefore, they have been counted in the individual courses which they studied.

Please see below for the number of graduates who studied more than one major:

- 127 graduates studied double majors in Architecture and Construction

- 12 graduates studied-double majors in Architecture and Real Estate

- 85 graduates studied double majors in Architecture and Urban Design and Regional Planning

- 56 graduates studied double majors in Construction and Real Estate 
- 15 graduates studied double majors in Construction and Urban Design and Regional Planning

- 15 graduates studied double majors in Real Estate and Urban Design and Regional Planning

- 2 graduates studied triple majors in Construction, Real Estate and Urban Design and Regional Planning

- 3 graduates studied triple majors in Architecture, Real Estate and Urban Design and Regional Planning

- 2 graduates studied triple majors in Architecture, Construction and Real Estate

- 6 graduates studied triple majors in Architecture, Construction and Urban Design and Regional Planning

If the graduates studied double or triple majors, they are counted in all the courses they studied but only once in the overall built environment category.

Dimensionality reduction was also used to produce the dataset for the salary classification for real estate graduates and built environment graduates, i.e. annual salary at AUD 50000 or below and above AUD50,000. An annual salary of AUD50,000 was chosen as a threshold as it follows Australian Bureau Statistics (ABS) threshold guidance for graduates' starting salary. Dimensionality reduction was also used to produce the dataset for contract type classification. Temporary contract includes any fixed contract of different length of time and casual contract, while permanent contract includes any type of permanent and open-ended contract.

As mentioned in Section 3.2, the majority of the respondents for AGS are Australian home-based students. Therefore, the authors have made the decision to only include the graduates who were Australian Permanent Residents in this study. The second reason for suggesting this arrangement is that there is a legal restriction for non-Australian Permanent Residents to seek employment in Australia and it will cause bias if including them in the analysis. Also, it is important to exclude the graduates who declared they were continuing on to further study as they were unlikely to seek fulltime graduate level employment. After taking these aspects into consideration, there were 5909 $(64 \%)$ built environment graduates considered in this study. Out of them, there were 991 real estate graduates, which constituted of $16.78 \%$ of built environment graduates. Please see Table 2 for the detailed information of real estate graduates and built environment graduates who were Australian Permanent Residents.

\section{INSERT TABLE 2 HERE}

\subsection{Analysis of gender and employment}

Descriptive and statistical analysis methods were used to analyse data in this paper. Descriptive statistics techniques were used to identify the impact of gender on employment outcomes, employment patterns, nature of role, salary, type of contract and employment opportunity in different States. The distribution of real estate and built environment graduates of different genders was reported in Table 3. The number and percentage of male and female graduates who have different employment outcomes, patterns and other important employment related issues as well as their respectively employment ratios to population were also identified (see Tables 4 to 9 ).

INSERT TABLE 3 HERE 
The next step is to identify the statistical significance of the influence of gender on individual variables of real estate and built environment graduates. $R$ programming language was also used to conduct the statistical analysis of this research. Chi-Squared Contingency 2-way analysis was used to test the six null hypotheses as stated in Section 2.2. The reason for using the 2-way analysis is to ensure the accuracy of the result. If the calculated value of the Chi-square test statistic is more than the critical value of 3.841 , which is equivalent to a 0.05 significance level, the null hypothesis is rejected. The critical value of 3.841 is used since it represents the critical value for a chi-square with 1 degree of freedom. If the calculated value of the test statistic is less than the critical value of 3.841 , which is equivalent to an above 0.05 significance level, the null hypothesis is accepted. The null hypothesis is that the two factors, i.e. gender and individual employment related variables, are independent of each other. If the null hypothesis is rejected, it means that the two variables are not independent of each other (Field et al., 2012).

Variables, such as employment outcomes, employment patterns, nature of role, salary and type of contract are binary variables. Despite some unknown answers for these categories, their sizes are insignificant and they are excluded in the analysis. For the States which real estate graduates and built environment graduates were resident, only New South Wales and Queensland were considered in the Chi-Squared Contingency 2-way analysis as they have the highest number of real estate graduates.

The phi coefficient was used to measure the correlation between gender and individual variables. The phi-coefficient was chosen as it is designed for the comparison of truly dichotomous distributions, i.e., distributions that have only two points on their scale which indicate some unmeasurable attribute. The value of phi correlation coefficient ranges from -1 to +1 , where $+/-1$ indicates perfect correlation between two variables and 0 indicates no relationship between two variables (Field et al., 2012).

\section{Research findings and discussions}

\subsection{Employment outcomes}

The percentages of male and female real estate graduates who were employed were $68.53 \%$ and $31.47 \%$ respectively. However, their employment to population ratios for male and female was $91.10 \%$ and $88.96 \%$ respectively, which means male real estate graduates are more likely to gain employment. The employment rate for male real estate graduates is higher than that overall for built environment graduates and this is reflected by the difference in the employment to population ratio. The ratio for male built environment graduates was $88.60 \%$, which is $2.50 \%$ lower than male real estate graduates. The unemployed real estate graduates consisted of $62.64 \%$ males and $37.36 \%$ females. Despite the larger numbers of male real estate graduates unemployed, it is female real estate graduates who were more likely to be unemployed because their unemployment to population ratios were $10.73 \%$ and $8.46 \%$ respectively. This finding is partially contrasted with Elias et al. (1999), McKnight (1999) and Smith et al.'s (2000) findings that males have higher employment rates but also have higher unemployment rates. The employment gap between male and female in the real estate and built environment sectors is lower than the overall pattern in Australia, the employment to population ratios for male and female were $74.4 \%$ and $61.7 \%$ (ABS, 2015a), which gives the difference on employment to population ratios for male and female real estate graduates as $12.7 \%$, as compared to $2.14 \%$ and $0.52 \%$ for real estate and built environment graduates. This shows that the gender imbalance between employment in the real estate and built environment sectors is lower than Australia's average. The chi-square test also showed that gender does not have a statistically significant impact on employment outcomes for real estate and built environment graduates. The chi-square values for employment outcomes and gender for real estate graduates and built environment graduates are 1.0598 and 0.1877 
respectively. They are smaller than the critical value of 3.841 , which means gender and employment outcomes are independent.

Please also see Table 4 and Table 10 for the distribution of graduates of different gender and different employment outcomes and information on statistical relationships between gender and individual employment related variables.

\section{INSERT TABLE 4 HERE}

\subsection{Employment patterns}

Male real estate graduates were more likely to be employed in a full-time role than their female counterparts, their employment to population ratio was $78.93 \%$ and $74.76 \%$ respectively. The percentage of male real estate graduates gaining full-time employment is higher than the built environment graduates, which was $76.18 \%$, while for female built environment graduates it was $68.37 \%$. Despite a higher proportion of male real estate graduates employed in full-time positions, the percentage was not as high as $92 \%$, which was reported in Fielden et al. (2000). There were a higher percentage of real estate females who had gained part-time employment too, and the employment to population ratio was $14.20 \%$ as compared to $12.17 \%$ for male. Despite the female's employment to population ratio for part-time roles being higher, it is still substantially lower than the findings stated by EOC (1997), which stated that $43 \%$ of women were employed in part-time positions compared with only $2 \%$ of men in 1996 . However, the difference in findings between the current and EOC's (1997) study is separated by nearly 20 years and so demonstrates a significant shift. Furthermore, the EOC (1997) study has a UK focus which may also be another reason which explains the difference with the current study. However, the current study also showed a different picture on the part-time employment rate between males and females in Australia. $64.57 \%$ of real estate graduates employed on a part-time basis were males and $35.43 \%$ were females. Based on the figures from ABS (2015a), $14.4 \%$ and $43.4 \%$ of part-time workers are males and females respectively, which means the real estate graduates were showing a different part-time employment pattern compared to the overall employment picture in Australia. In the same way as employment outcomes, there was no statistical relationship between gender and employment patterns for real estate graduates as the chi-square value is 0.8725 , which is smaller than critical value of 3.841 (see Table 10). On the other hand, it is statistically proven that gender has an impact on employment patterns for built environment graduates as the chi-square value is 52.918 (see Table 10). This comment is further reinforced by the value of the phi coefficient of 0.1 , which means there is a low positive relationship between gender and employment pattern (see Table 11) (Jones, 2015). Male built environment graduates were more likely to gain full-time posts; their employment to population ratio was $76.18 \%$ while for females it was $68.37 \%$.

Please also see Table 5 and Table 11 for the distribution of graduates with different gender and different employment patterns and the information on correlation between gender and individual employment related variables.

\section{INSERT TABLE 5 HERE}

\subsection{Nature of roles}

There was a higher percentage of female real estate graduates working in secretarial or administrative roles (including managerial and specialist, such as human resources and public 
relations), as their employment to population ratio was $17.03 \%$ as compared to $12.61 \%$ for male real estate graduates. On the other hand, the employment to population ratio for females working in professional or technical roles was $58.99 \%$, which was lower than the ratio for males at $61.28 \%$. This finding echoed with Dainty et al. (2000) and Fielden et al. (2000)'s research which stated that females are more likely to work in supporting, secretarial and administrative roles while their male counterparts are more likely to be employed in the technical and professional categories. There was a lower percentage of built environment graduates than real estate graduates working in secretarial or administrative roles, the percentages for females and males working in this type of role are $10.63 \%$ and $5.21 \%$ respectively. Based on the raw information which presents the nature of roles for real estate and built environment graduates, it shows there were no female real estate graduates working in human resources roles whilst there were three male real estate graduates in this kind of role. It is the same case for built environment graduates, there were two female built environment graduates working as human resource advisors whilst six male built environment graduates work in this kind of role. There was a higher percentage of male built environment graduates working in professional or technical roles with the employment to population ratio of $70.70 \%$ as compared to $64.67 \%$ for females. The impact of gender on gaining different roles for built environment graduates is also statistically significant, as the chi-square value is 61.4075 , which is higher than the critical value of 3.841 (see Table 10). Gender and nature of role has a low negative relationship as its phi coefficient value is -0.12 (see Table 11). On the other hand, gender did not have a statistically significant impact on the nature of roles for real estate graduates, as the chi-square value is 2.6912 only, which is lower than the critical value.

Please also see Table 6 for the distribution of graduates with different genders who have different nature of roles.

\section{INSERT TABLE 6 HERE}

\subsection{Salary}

Male real estate graduates earned a higher level of salary than female graduates. The employment ratios for male real estate graduates who worked full-time and earned more than AUD 50,000 per annum was $36.35 \%$ as compared to $26.81 \%$ females. The reason for comparing graduates who worked full-time only is that they will work for a comparable number of hours each week. Graduates who worked part-time may work for highly variable numbers of hours whilst still being classed as part-time so it does not form a consistent basis for comparison. The male built environment graduates were also likely to have higher earnings than their female counterparts. The employment ratios for male and female built environment graduates worked full-time and earned more than AUD 50,000 per annum was $39.61 \%$ and $28.72 \%$ respectively. This finding is statistically significant as the values for chi-square for salary and gender for real estate and built environment graduates who worked full-time were 10.1389 and 37.3307 and their phi coefficient values were -0.12 and -0.10 , which means gender and salary for real estate and built environment graduates have low negative relationships (Jones, 2015). The salary difference between different genders for real estate and built environment graduates aligned with the overall pattern in Australia as Evershed (2014) stated that females in Australia earn 18.2\% less than men and the ABS statistics showed that the gender gap between male and female pay is at a 20-year high in 2014. It also shared the findings from the research focused in the UK, such as Artess et al. (2008) and Elias et al. (1999) stated that males have higher salary levers than females.

Please also see Table 7 for the distribution of graduates of different genders by levels of salary.

INSERT TABLE 7 HERE 


\subsection{Type of contract}

Female real estate graduates were slightly more likely to be employed on permanent contracts. The employment to population ratios for male and female real estate graduates employed on permanent contracts was $68.99 \%$ and $69.40 \%$ respectively. There was also a higher percentage of male real estate graduates employed in temporary/ fixed term/ casual contracts too. The employment ratios for male and female real estate graduates employed on temporary contracts were $19.58 \%$ and $18.93 \%$ respectively. However, the impact of gender on the type of contract which real estate graduates are employed is not statistically significant as the chi-square value was 0.0093 . On the other hand, it is statistically significant that gender has an impact on the type of contract built environment graduates are employed under. The chi-square value is 23.9767 (see Table 10) and the value for phi coefficient is 0.07 (see Table 11), this means there is a negligible positive relationship between gender and type of contract for built environment graduates. Male built environment graduate were more likely to be employed on permanent contracts. The employment to population ratios for male and female built environment graduates working on a permanent contract was $62.19 \%$ and $56.58 \%$ respectively.

Please also see Table 8 for the distribution of graduates of different gender who have different types of contract.

\section{INSERT TABLE 8 HERE}

\subsection{Employment opportunities in different States}

The real estate graduates' employment to population ratio in Victoria was the highest among all states, $94.34 \%$, while Queensland is the third and New South Wales is the fifth with employment rates of $90.13 \%$ and $87.91 \%$ respectively. Queensland had the lowest employment rate for male real estate graduates, $63.09 \%$, and the highest female employment rate of $36.91 \%$. The employment to population ratios for males and females in New South Wales were $90.20 \%$ and $83.33 \%$, while in Queensland they were $91.84 \%$ and $87.21 \%$. Despite the difference in the employment rate and employment ration between males and females in these two States, the difference is not statistically significant as the value for chi-square is less than 3.841 (see Table 10). It is the same case for the employment situation for the built environment graduates too as the chi-square for gender and States (New South Wales and Queensland) is smaller than the critical value of 3.841 .

Please see Table 9 for the distribution of graduates of different gender who work in different States. Please also see Table 12 for summary of results on research hypotheses testing.

INSERT TABLE 9 HERE

INSERT TABLE 10 HERE

INSERT TABLE 11 HERE 


\section{Conclusions}

This paper investigated the impact of gender on real estate graduates' employment outcomes, employment patterns and other important employment related issues, such as pay, role, contract type and employment opportunity in different States, and also benchmarks findings of the employment issues of real estate graduates to the built environment graduates.

Male real estate and built environment graduates were more likely to gain employment than their female counterparts, but the finding was not found to be statistically significant. In relation to employment patterns, male built environment graduates were more likely to gain full-time employment and this finding was found to be statistically significant. The dominant role for female real estate and built environment graduates is a secretarial or administrative role while for male graduates it is a professional or technical role. The difference in role for built environment graduates of different genders is statistically significant. Male real estate and built environment graduates and were more likely to have a higher level of salary and this is statistically significant. Gender also has impact on the contract type. Male built environment graduates were more likely to be employed on a permanent contract and the finding is statistically significant. On the other hand, gender has no impact on gaining employment in New South Wales and Queensland in Australia.

Despite the Australian government has implementing legislation, such as the Sex Discrimination Act of 1984, the Affirmative Action Act of 1986 and the Victorian Building Industry Agreement of 1989 , to enhance employment equality since the 2000 s, this study found that male real estate and built environment graduates still had more favourable employment opportunities and on better employment terms. The finding of this paper reinforces the view of previous studies on gender and employment for built environment professionals which were conducted in 1990s (Connor et al., 1997; Elias et al., 1999; McKnight, 1999) in 2000s (Artess et al., 2008; Dainty et al., 2000; Fielden et al., 2000 Smith et al., 2000), in 2010s (Francis,2010; Francis and Prosser, 2014) and in other countries, such as the UK (Devaney and Roberts, 2012), Sweden (Staffansson Pauli, 2013), USA (Bilbo and White, 1999 and Bilbo et al., 2014) and in Thailand (Kaewsri and Tongthong. 2014).

One of the findings of the current research is that female real estate graduates were more likely to find work in part-time roles although the difference between the two genders is not statistically significant. There is a traditional view that females prefer to work part-time in order to raise family. Research findings of previous research focused on the UK, such as EOC (1997) and Fielden et al. (2000) showed that female graduates in the UK were more likely to work part-time, however this study did not find a statistically significant difference between numbers of male and female graduates working in part-time roles for Australia. However, this paper did find that female real estate and built environment graduates employed on a full-time basis have a statistically significant negative salary gap as compared with their male counterparts.

The findings of this paper also concluded that female real estate graduates are more likely to work in administrative or secretarial roles than in professional or technical roles. Although, the difference in the employment outcome between male and female graduates is not statistically significant, i.e. gender was found not to be factor in gaining employment. Real estate courses are usually professionally-accredited vocational courses and graduates studying these courses usually have clear career aspirations. The authors were surprised to see that female real estate graduates were more likely to work in these more generic roles which do not follow the expected career path of their Degree course. It would be good to conduct further research on the career aspirations of female real estate graduates in order to identify the reasons for them to embark a career in an administrative or secretarial role. Real estate course providers could use the future research 
findings to develop strategies and measures to encourage and motivate female real estate graduates to develop a career in professional or technical role.

\section{References}

Artess, J., Ball, C. and Mok, P. (2008), Higher Degrees: Postgraduate Study in the UK 2000/01 to 2005/06, DIUS Research Report 08-16, Department for Innovation, Universities and Skills, London, UK.

Australian Bureau of Statistics (ABS) (2015a), 4125.0 - Gender Indicators, Australia, August 2014. Available at

http://www.abs.gov.au/ausstats/abs@.nsf/Lookup/4125.0main+features110August\%202014 (Last accessed 5 January 2015).

Australian Bureau of Statistics (ABS) (2015b), 6202.0 - Labour Force, Australia, Nov 2014.

Available at

http://www.abs.gov.au/AUSSTATS/abs@.nsf/DetailsPage/6202.0Nov\%202014?OpenDocument\# Publications (Last accessed 5 January 2015).

Australian Graduate Survey (AGS) (2015), Australian Graduate Survey. Available at http://www.graduatecareers.com.au/research/surveys/australiangraduatesurvey/ (last accessed: 5 January 2015).

Avera, M. W. (2007), "Women in construction". Top building jobs, $5^{\text {th }}$ June.

Bilbo, D.L., and White, N.J. (1999), "Ten common questions from women entering the construction industry: two perspectives". The American Professional Constructor, Vol. 23 No. 2, pp. 2-12.

Bilbo, D., Bigelow, B.F., Rybkowski, F. Kamranzadeh, A. (2014), "Effects of family-related factors on female project managers' salaries in the construction industry in the United States". International Journal of Construction Education and Research, Vol. 10 No.4, pp. 255-267

Cartwright, B., Edwards, P.R., and Wang, Q. (2011), "Job and industry gender segregation: NAICS categories and EEO-1 job groups”. Monthly Labour Review, November, pp.37-50.

Clarke, K. and Wall, C. (1998), "UK construction skills in the context of European developments". Construction Management and Economics, Vol. 16, pp. 553-567.

Connor, H., La Valle, I., Pollard, E. and Milmore, B. (1997), What do graduates do next? Report 343, Institute for Employment Studies, London, UK.

Conway, D. and White, J.M. (2012), Machine learning for hackers, O’Reilly, New York, USA.

Court, G. and Moralee, J. (1995), Balancing the Building Team: Gender Issues in the Building Professions, Institute for Employment Studies/CIOB, University of Sussex, Sussex, UK.

Dainty, A., Bagilhole, B. and Neale, R. (2000), "A grounded theory of women's career underachievement in large UK construction companies". Construction Management and Economics, Vol. 18, pp.239-250.

Dainty, A.R.J. and Lingard, H. (2006), "Indirect discrimination in construction organizations and the impact on women's careers”. Journal of Management in Engineering, Vol. 22, pp.108-118. 
Devaney, S. and Roberts, D. (2012), "Who gets the jobs? Factors influencing the employability of property and construction graduates in the UK". Construction Management and Economics, Vol. 30, pp. 233-246.

Elias, P., McKnight, A., Pitcher, J., Purcell, K. and Simm, C. (1999), Moving On: Graduate Careers Three Years after Graduation, Careers Service Unit/Department for Education and Employment, Manchester, UK.

Employment Service (1997), Statistical update: quarterly projections of the new earnings survey, July 1997, Labour Market Trends, November, pp. 446-467.

EOC (1997), Briefings on Women and Men in Britain: The Labour Market, Equal Opportunities Commission, Manchester, UK.

Evershed, N. (2014), Statistics show the gender gap between male and female pay is at 20-year high. The Guardian, 5 September 2014. Available at

http://www.theguardian.com/news/datablog/2014/sep/05/statistics-show-the-gender-gap-betweenmale-and-female-pay-is-at-20-year-high (Last accessed 5 January 2015).

Field, A., Miles, J. and Field, Z. (2012), Discovering Statistics Using R., SAGE Publications Ltd., London, UK.

Fielden, S. L. Davison, M. J., Gale, A. W. and Davey, C. L. (2000), "Women in construction: the untapped resource". Construction Management and Economics, Vol. 18, pp.113-121.

Francis, V. (2010), "A twenty year review of women's participation within the construction trade sector of the Australian construction industry", Proceedings of the RICS Foundation Construction and Building Research Conference, COBRA, London, England, UK.

Francis, V.B.E., and Prosser, A. (2014), "Exploring vocational guidance and gender in construction". International Journal of Construction Education and Research, Vol. 10 No.1, pp. 3957.

Gale, A.W. (1994), "Women in non-traditional occupations: The construction industry". Women in Management Review, Vol. 9 No. 2, pp. 3-14.

Gilbert, G. L. and Walker, D.H.T. (2001), "Motivation of Australian white-collar construction employees: a gender issue?." Engineering, Construction end Architectural Management, Vol. 8, pp. 59-66.

Greed, C. (2000), "Women in the construction professions: achieving critical mass". Gender, Work and Organisation, Vol. 7 No. 3, pp. 181-196.

Greed, C. (2006), "Social exclusion: Women in construction", in Gale, A., and Davidson, M. (Eds.) Managing Diversity in Construction, Spon, London, UK, pp. 71-97.

Gurjao, S. (2007), Inclusivity: The changing role of women in the construction workforce, Chartered Institute of Building (CIOB), Ascot, England, UK.

Jones, L. (2015), Objective 3: Tests of association for nominal data. Available at http://www.angelo.edu/faculty/ljones/gov3301/block14/objective3.htm (last accessed: 5 January 2015). 
Kaewsri, N. and Tongthong. T. (2014), "Favourable female attributes in relation to career challenges of women engineers in the Thai construction industry". International Journal of Construction Education and Research, Vol. 10 No. 3, pp.222-236.

Lingard, H., and Lin, J. (2004), "Career, family and work environment determinants of organizational commitment among women in the Australian construction industry". Construction Management and Economics, Vol. 22, pp. 409-420.

McKnight, A. (1999), "Graduate employability and performance indicators: first destination and beyond': in Moving on: Graduate Careers Three Years After Graduation, CSU/ DfEE/ IER, Manchester, UK.

National Association of Women in Construction (2010), NAWIC Facts September. Available at http://www.nawic.org/images/nawic/documents/brochures/factsheet.pdf (Last accessed 8 January 2015).

Pyke, J. (1993), Women in Building; The Missing 51\%, Australian Government Publishing Service, Canberra, Australia.

Scurry, T. and Blenkinsopp, J. (2011),"Under-employment among recent graduates: a review of the literature", Personnel Review, Vol. 40 No 5, pp. $643-659$.

Smith, J., McKnight, A. and Naylor, R. (2000), "Graduate employability: policy and performance in higher education in the UK". Economic Journal, Vol.110 June, pp. F382-F411.

Staffansson Pauli, K.M., (2013), "All of my bosses have been men - on gender structures in the real-estate industry". Property Management, Vol. 31 No. 5, pp. 420 - 434.

U.S. Department of Labor. (2010). Women in the labour force: A databook. Washington, DC: Bureau of Labour Statistics, Report 1026. Available at http://www.bls.gov/cps/wlf-databook2010.pdf (Last accessed 8 January 2015).

Watts, J.H. (2009), "Allowed into a man's world": Meanings of work-life balance: Perspectives of women civil engineers as minority' workers in construction". Gender, Work and Organisation, Vol.16 No. 1, pp.37-57. 